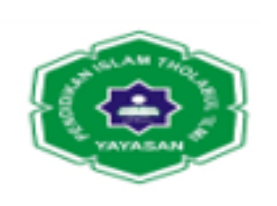

Jurnal Ilmiah METADATA

\title{
PENERAPAN HUKUM TERHADAP ASAS KEPERCAYAAN DI DALAM TRANSAKSI JUAL-BELI ON-LINE
}

\author{
M. Faisal Rahendra Lubis \\ Universitas Islam Sumatera Utara \\ E-mail: rahendra_rif@yahoo.co.id
}

\begin{abstract}
Abstrak
Perkembangan teknologi memang telah memberikan dampak positif terhadap perkembangan hukum bisnis, terutama sejak dikembangkannya internet. Melakukan transaksi jual-beli secara on-line adalah salah satu dari bentuk berkembangnya teknologi. Masyarakat melakukan transaksi jual-beli tidak perlu betatap muka langsung terhadap penjualnya melainkan bisa membeli suatu barang dengan mudah dan dirumah saja. Dalam melakukan transaksi tersebut penjual maupun pembeli harus melakukan perjanjian jual-beli secara on-line dimana melakukan jual-beli secara on-line tersebut haruslah memenuhi unsur-unsur dalam perjanjian jual-beli. Perjanjian jual-beli secara on-line tersebut sangat memerlukan suatu kepercayaan antara penjual dan membeli. Asas kepercayaan sangat penting dalam kegiatan jual-beli karena kepercayaan dapat menimbulkan sebuah keyakinan. Oleh karena itu penjual dan pembeli terlebih dahulu harus menumbuhkan kepercayaan di antara mereka, bahwa satu sama lain akan memenuhi janji yang di telah disepakati. Penerapan hukum terhadap asas kepercayaan dalam transaksi jual-beli on-line terdapat dalam Pasal 1338 KUHPerdata yaitu bahwa dalam melakukan suatu perjanjian jual-beli harus dilaksanakan dengan itikad baik dari penjual maupun pembeli.
\end{abstract}

Kata Kunci: Penerapan Hukum, kepercayaan, Transaksi Jual-beli On-line.

\begin{abstract}
Technological developments have indeed brought about positive effects on bussiness law, especially since the developed of the internet. Engaging in on-line trades is one of the many technological advances. People do not need to come face to face with their sellers but can buy goods at home easily. Both the seller and the buyer must enter into an on-line trading agreement in which such on-line trades should meet the elements of the agreement. Such on-line trading agreements require a measure of trust between seller dan buyer. The principle of trust is essential in trading because trust can engender a confidence. Therefore the seller an buyer must first cultivate confidence among themselves that each other will fulfill the agreed promise. The application of the law to the principle of trust in on-line trading is found in chapter 1338 KUHPerdata that in undertaking a purchase agreement must be implemented in good faith from the seller dan the buyer.
\end{abstract}

Keywords: Application Of The Law, Confidence, Trading Transactions On-line. 


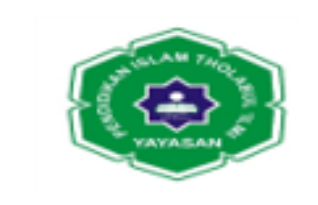

\section{Jurnal Ilmiah METADATA}

\section{PENDAHULUAN}

Di zaman yang serba canggih dan modern ini, hampir segala sesuatu tidak terlepas dengan internet, termasuk juga soal bisnis. Jika kita bicara soal bisnis atau usaha tentunyatidak terlepas dengan kegiatan pemasaran, jual-beli, atau marketing. Perkembangan internet menciptakan terbentuknya suatu dunia baru yang biasa disebut dengan dunia maya (cyberspace). Perkembangan tersebut berakibat juga pada aspek sosial, dimana cara berhubungan antar manusia pun ikut berubah. Hal ini secara tidak langsung berpengaruh terhad ap sektor bisnis.

Globalisasi pada saat ini telah berjalan di dunia maya yang menghubungkan langsung seluruh komunitas digital, seakan-akan dunia berada dalam gegaman kita. Seluruh aspek kehidupan manusia terkena dampak kehadiran internet. Sektor perdagangan merupakan yang paling terkena dampak dari perkembangan teknologi informasi tersebut. Jika kita bicara soal bisnis ataupun perdagangan atau usaha tentunya tidak terlepas dengan kegiatan pemasaran, jual-beli, atau marketing. Perkembangan teknologi informasi yang semakin pesat pada saat sekarang ini membuat aliran informasi menjadi semakin mudah.

Internet merupakan sarana teknologi terpopuler dan digunakan oleh hampir seluruh masyarakat Indonesia untuk mengakses informasi secara on-line cepat, mudah, dan praktis. "Teknologi dan informasi juga dibutuhkan manusia untuk membantu dan mempermudah pekerjaan manusia sehingga menjadi lebih efektif dan efisien". 'Saat ini, sebagian besar dari kalangan masyarakat kita sudah menggunakan internet dalam kesehariannya, baik sebagai sarana untuk mencari informasi, bersosialisasi atau bahkan sebagai sarana untuk mencari penghasilan untuk kehidupan yang lebih lanjut.

Dalam kaitan dengan penggunaan teknologi informasi Wiradipradja dan Budhijanto mengatakan: "Sistem informasi dan teknologinya telah digunakan di banyak sektor kehidupan, mulai dari perdagangan/bisnis (electronic commercelecommerce), pendidikan (electronic education), kesehatan (telemedicine), telekarya, transportasi, ind ustri, pariwisata, lingkungan sampai ke sektor hiburan, bahkan sekarang timbul pula untuk bidang pemerintahan (egovernment)". ${ }^{2}$

Perdagangan saat ini tidak hanya dilaksanakan secara konvensional yaitu secara lisan atau tertulis, melainkan sudah dilaksanakan melalui elektronik yaitu dengan menggunakan komputer, gadget (internet). Pada saat ini tidak sedikit masyarakat yang melakukan transaksi jual-beli melalui on-line elektronik (ecommerce). Transaksi e-commerce seperti halnya transaksi perdagangan dalam dunia usaha yang pada umumnya merupakan suatu perjanjian antara penjual dan pembeli. Para pihak dalam transaksi e-commerce sering disebut merchant dan customer. Kedudukan merchant dan customer sama seperti kedudukan para pelaku usaha dalam dunia perdagangan konvensional, penjual dan pembeli.

${ }^{1}$ Hikmahanto Juwana, Hukum Ekonomi dan Hukum Internasional, Jakarta, Lentera Hati, 2002, h. 23.

2 E.S. Wiradipradja dan D. Budhijanto, Perspektif Hukum Internasional tentang Cyber Law dalam Kantaatmadja, et al, Cyberlaw: Suatu Pengantar, Jakarta, Elips 11, 2002, h.88. 


\section{(ㄷ)}

\section{Jurnal Ilmiah METADATA}

Penerapan perdagangan melalui media internet ini menyebabkan perubahan baru pada sektor bisnis. Seperti pemanfaatan E-Commerce sebagai media perdagangan yang menggunakan media internet yang dapat dijangkau oleh semua kalangan. Selain itu E-Commerce juga dapat diartikan sebagai suatu cara berbelanja atau berdagang secara on-line yang memanfaatkan fasilitas media internet dimana terdapat website yang dapat menyediakan layanan get and deliver. ${ }^{3} \mathrm{Hal}$ ini memberikan kemudahan dalam melakukan kegiatan bisnis meskipun salah satu rekan bisnis berada di daerah lain atau di Negara lain.

Pada transaksi jual-beli on-line ini berawal dari penawaran dan penerimaan. Penawaran yaitu suatu perbuatan seseorang bahwa perbuatan itu sendiri sebagai ajakan untuk masuk kedalam ikatan perjanjian ${ }^{4}$. Dasar ini terjadinya perjanjian dalam suatu transaksi adalah adanya suatu asas kepercayaan. Rasa percaya selalu saja dijadikan manusia sebagai tolak ukur dalam suatu hubungan termasuk hubungan didalam bertransaksi jual-beli secara on-line. Dikarenakan dalam bertransaksi on-line kedua belah pihak tidak dapat bertemu secara langsung. Sehingga kepercayaan adalah faktor utama yang sangat penting dalam suatu aktivitas transaksi jual-beli on-line ini dan merupakan suatu pondasi dari pada suatu perjanjian. Kepercayaan adalah suatu keadaan psikologis pada saat seseorang menganggap sesuatu itu benar.

"Asas kepercayaan dalam suatu perjanjian yaitu seseorang yang mengadakan perjanjian dengan pihak lain, menumbuhkan kepercayaan diantara kedua belah pihak itu bahwa satu sama lain akan memegang janjinya dengan kata lain akan memenuhi prestasinya dibelakang hari". ${ }^{5}$ Tanpa ad anya kepercayaan itu maka perjanjian itu tidak mungkin akan diadakan kedua belah pihak, dengan kepercayaan ini kedua pihak mengikatkan dirinya dan untuk keduanya perjanjian itu mempunyai kekuatan mengikat sebagai Undang-Undang.

Suatu transaksi on-line antara duabelah pihak atau lebih akan terjadi apabila masing-masing saling percaya. Kepercayaan tidak dapat begitu saja diakui oleh pihak lain atau mitra bisnis, melainkan harus dibangun mulai dari awal dan dapat dibuktikan. Ketika seseorang ingin melakukan transaksi secara on-line, maka harus ada dipikirannya bahwa uang yang dikirimkannya tidak hilang begitu saja tetapi mendapatkan balasan produk yang diinginkan sesuai dengan apa yang ditampilkan dan dijelaskan secara terperinci dari penjual melalui on-line.

Ketika seseorang berbelanja on-line, hal utama yang menjadi pertimbangan seorang pembeli adalah apakah mereka percaya kepada website yang menyediakan on-line shoping dan penjual on-line pada website tersebut. Kepercayaan pembeli terhadap suatu penjual on-line terletak pada populer atau tidaknya website tersebut. Selanjutnya, kepercayaan pembeli terhad ap website toko on-line juga terkait dengan kehandalan penjual yang menjual produknya di toko on-line terkait barang yang

${ }^{3}$ Assafa Endeshaw, Hukum E-Commerece dan Internet dengan fokus di Asia Pasifik, Yogyakarta, Pustaka Pelajar, 2007,h.3.

${ }_{4}^{4}$ Mariam Darus Badrulzaman, E-Commerce Tinjauan Dari Hukum Kontrak Indonesia, Jakarta, Citra Aditya Bakti, 2001, h.33.

5 M Nasrullah Yusuf, Strategi membangun nilai jasa dan kepercayaan pelanggan, Jakarta, Deepublish, 2014, h.64. 


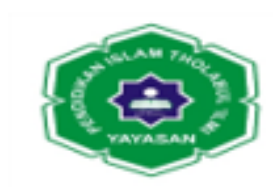

\section{Jurnal Ilmiah METADATA}

dikirim setelah melakukan transaksi atau pembayaran dan barang tersebut akan sama keadaannya dengan yang di upload.

Sedangkan yang kita jumpai dalam kehidupan masyarakat pada umumnya dalam transaksi jual-beli on-line adalah hal-hal yang tidak sesuai dengan apa yang kita harapkan pada saat pertama kali terjadi perjanjian jual-beli. Seperti barang tidak sesuai dengan gambar, harga tidak sesuai dengan kualitas, ataupun setelah terjadi proses pembayaran barang yang dipesan tidak dikirim (tidak dapat diterima oleh pembeli). Dengan kejadian-kejadian seperti ini maka akan berpengaruh pada kepercayaan kita terhadap suatu transaksi elektronik. Dikarenakan kita sebagai pembeli merasa dirugikan oleh para pihak-pihak yang tidak bertanggung jawab dalam hal ini lebih tertuju ke penjual.

\section{METODE PENELITIAN}

Penelitian ini tergolong sebagai penelitian hukum normatif. Data penelitian ini bersumber dari data sekunder yang bersumber dari bahan-bahan hukum, yang terdiri dari bahan hukum primer, sekunder dan tersier. Penelitian ini menggunakan pendekatan undang-undang dan pendekatan konseptual. Analisis data dalam penelitian ini menggunakan analisis data kualitatif.

\section{HASIL DAN PEMBAHASAN}

\section{A. Asas Kepercayaan Di Dalam Transaksi Jual-beli On-line}

1. Asas Kepercayaan

Asas kepercayaan mengandung pengertian bahwa setiap orang yang akan mengadakan suatu bentuk perjanjian yang akan memenuhi setiap prestasinya yang diadakan diantara mereka dibelakang hari. Asas kepercayaan sangat penting dalam kegiatan jual-beli karena kepercayaan dapat menimbulkan sesuatu keyakinan. Oleh karena itu para pihak terlebih dahulu harus menumbuhkan kepercayaan di antara mereka, bahwa satu sama lain akan memenuhi janji yang di sepakati atau melaksanakan prestasinya dikemudian hari. "Dengan kepercayaan kedua belah pihak mengikatkan dirinya kepada kontrak yang mempunyai kekuatan mengikat sebagai Undang-Undang sebagaimana di tentukan Pasal 1338 ayat (1) KUHPerdata". ${ }^{6}$

Dalam Pasal 1457 KUHPerdata diatur tentang pengertian jual-beli merupakan satu perjanjian dengan mana pihak yang satu mengikatkan dirinya untuk menyerahkan satu benda dan pihak lain membayar harga yang telah di janjikan. Dalam pelaksanaan transaksi jual-beli secara on-line, kepercayaan konsumen atau pembeli akan menjadi faktor yang utama. Karena kegiatan ini dilakukan secara online yaitu pihak penjual dan pihak pembeli tidak bertatap muka secara langsung.

Kepercayaan adalah keyakinan bahwa seseorang akan menemukan apa yang ia inginkan pada mitra pertukaran. "Kepercayaan melibatkan ketersediaan seseorang untuk bertingkah laku tertentu karena keyakinan bahwa mitranya akan memberikan apa yang ia harapkan dan suatu harapan yang umumnya dimiliki

${ }^{6}$ Hermansyah, Perwujudan Asas Kepercayaan Dalam Pengaturan Kegiatan Usaha Bank, Skripsi Sarjana, Fakulta Ilmu Hukum Universitas Tanjungpura, Pontianak, 2015, h.3 . 


\section{(ㄷ)}

\section{Jurnal Ilmiah METADATA}

seseorang bahwa kata, janji atau pernyataan orang lain dapat di percaya". ${ }^{7}$ Oleh karena itu asas kepercayaan merupakan hal yang paling utama untuk bisa terjadinya sebuah jual-beli secara on-line.

\section{Perjanjian.}

a. Pengertian Perjanjian.

Definisi Kontrak atau perjanjian Pada prinsip kontrak terdiri dari satu atau serangkaian janji yang dibuat para pihak dalam kontrak. Esensi dari kontrak itu sendiri adalah perjanjian (agreement). "Suatu perjanjian adalah suatu peristiwa dimana dua orang itu saling berjanji untuk melaksanakan suatu hal". ${ }^{8}$ Perjanjian ini mempunyai kekuatan hukum yang sama dengan perundang-undangan, yang artinya perjanjian yang dibuat oleh pihak tertentu dapat dijadikan dasar hukum bagi yang membuatnya.

Perbedaan perjanjian dengan perundang-undangan adalah dalam hal bahwa perjanjian hanya berlaku bagi pihak yang membuatnya saja tidak mengikat orang lain atau masyarakat umum, sedangkan perundang-undangan berlaku umum kepada pihak yang menjadi subjek pengaturannya. "Suatu perjanjian adalah semata-mata suatu persetujuan yang diakui oleh hukum, artinya persetujuan ini merupakan kepentingan pokok dalam dunia usaha, dan menjadi dasar dari kebanyakan transaksi dagang". 9

Pada intinya perjanjian diperlukan untuk menjaga para pihak dalam menjalankan sesuatu kegiatan bisnisnya dapat terjaga atau adanya suatu kepastian hukum untuk menjadikan pelaksana bisnis aman dan tentram, maka diperlukan suatu perangkat hukum yaitu perjanjian. Dengan ad anya suatu perjanjian maka akan menjadi suatu pengikat dan menjadi Undang-Undang kedua belah pihak. Oleh karena itu perjanjian yang dibuat tidak boleh dilanggar oleh para pihak didalamnya, karena apabila dilanggar maka salah satu pihak akan mendapatkan sanksi dari perjanjian tersebut.

Bab II Buku III Kitab Undang-Undang Hukum Perdata (KUHPerdata) Indonesia menyamakan kontrak dengan perjanjian atau persetujuan. Hal tersebut secara jelas terlihat dalam judul Bab II Buku III KUHPerdata, yakni "Perikatan yang Lahir dari kontrak atau persetujuan". Pasal 1313 KUHPerdata mendefinisikan perjanjian sebagai suatu perbuatan yang terjadi antara satu atau dua orang atau lebih mengikatkan dirinya terhadap orang lain.

Menurut Pasal 1320 KUHPerdata bahwa suatu perjanjian yang sah diperlukan 4 syarat, yaitu:

1. Sepakat mereka yang mengikat dirinya;

2. Kecakapan untuk membuat suatu perikatan;

3. Suatu hal tertentu;

4. Suatu sebab yang halal.

7 Harman Malau, Manajemen Pemasaran Teori Dan Aplikasi Pemasaran Era Traditisional Sampai Era Modernisasi Global, Cv. Alfabeta, Bandung, 2018, h.301.

${ }^{8}$ R. Subekti, Hukum Perjanjian, PT. Intermasa, Jakarta, 2002, h.1.

${ }^{9}$ Abdul Kadir Muhammmad, Hukum Perjanjian, PT. Citra Aditya Bakti, Bandung, 2006, h.93. 


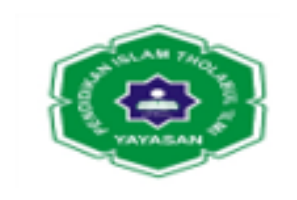

\section{Jurnal Ilmiah METADATA}

Keempat syarat di atas merupakan syarat pokok bagi setiap perjanjian, artinya setiap perjanjian harus memenuhi keempat syarat ini bila ingin menjadi perjanjian yang sah. Keempat syarat pokok ini dapat dikelompokkan dalam dua kelompok, yaitu kelompok syarat subjektif dan kelompok syarat objektif. ${ }^{10}$ Syarat subjektif mencakup adanya unsur kesepakatan dan kecakapan dari pihak yang melaksanakan perjanjian, sedangkan syarat objektif meliputi objek yang diperjanjikan dan haruslah sesuatu yang tidak dilarang menurut hukum.

Tidak terpenuhinya salah satu unsur dari keempat syarat tersebut mengakibatkan cacat dalam perjanjian dan perjanjian tersebut diancam dengan kebatalan, baik dalam bentuk dapat dibatalkan (jika terdapat pelanggaran terhadap syarat subjektif) maupun batal demi hukum (dalam hal ini tidak terpenuhinya syarat objektif). ${ }^{11}$

b. Syarat-syarat Sahnya Suatu Perjanjian.

Pada ketentuan umum mengenai perjanjian yang diatur dalam KUHPerdata, suatu perjanjian tidak diharuskan untuk dibuat secara tertulis, kecuali untuk perjanjian-perjanjian tertentu yang secara khusus disyaratkan adanya formalitas ataupun perbuatan (fisik) tertentu.

Dalam ketentuan Pasal 1320 KUHPerdata dikatakan bahwa perjanjian sah jika:

1) Dibuat berdasarkan kata sepakat dari para pihak; tanpa adanya paksaan, kekhilafan maupun penipuan;

2) Dibuat oleh mereka yang cakap untuk bertindak dalam hukum;

3) Memiliki objek perjanjian yang jelas;

4) Didasarkan pada satu klausula yang halal.

Menurut Salim HS. di dalam Hukum Kontrak atau Hukum Perjanjian, dikenal ad anya asas-asas penting yaitu:

1) Asas kebebasan berkontrak;

2) Asas konsensualisme;

3) Asas kepastian hukum (asas pacta sunt servanda);

4) Asas itikad baik, dan asas kepercayaan. ${ }^{12}$

c. Unsur-Unsur Perjanjian

Patuh dan taat pada komitmen adalah suatu keharusan untuk mempertahankan keberlangsungan dari bisnis yang sedang atau telah dijalankan maka para pihak untuk menghormati dan menghargai perjanjian adalah mutlak untuk terus dilakukan.

Adapun unsur-unsur dari perjanjian antara lain sebagai berikut:

1) Essentialia, yang artinya syarat sahnya perjanjian;

2) Naturalia, artinya lazim melekat pada perjanjian;

${ }^{10}$ Hardijan Rusli, Hukum Perjanjian Indonesia dan Common Law, Jakarta, Pustaka Sinar Harapan, 1993, h.44.

11 Kartini Muljadi dan Gunawan Widjaja,Seri Hukum Perikatan, Jakarta, Raja Grafindo Persada, 2003, h.93.

12 Salim HS, Hukum Kontrak: Teori dan Teknik Penyusunan Kontrak, Jakarta, Sinar Grafika, 2006, h.9. 


\section{(2)}

\section{Jurnal Ilmiah METADATA}

3) Accidentalia, artinya yang harus disebut tegas. ${ }^{13}$

Dalam ketiga unsur perjanjian diatas, dapat ditarik kesimpulan bahwa suatu perjanjian perjanjian akan berlangsung dengan benar jika syarat sahnya terpenuhi seperti tertuang dalam Pasal 1320 KUHPerdata, dimana hal yang dapat di perjanjikan merupakan hal yang lazim serta adanya ketegasan dari perjanjian tersebut.

Hal-hal yang timbul dari aktifitas perjanjian antara lain yaitu:

1) Merupakan pertemuan antara penawaran dan penerimaan;

2) Aktivitas perdata/pribadi;

3) Dirancang sesuai dengankesepakatan para pihak yang berkontrak;

4) Berlaku dan mengikat parapihak yang menyepakatinya;

5) Tidak boleh dilakukan peruahan secara sepihak jika sudah di setujui;

6) Tidak boleh disepakati melalui orises paksaan, penipuan. ${ }^{14}$

d. Asas-asas Dalam Perjanjian.

Departemen kehakiman dari tanggal 17 s/d 19 Desember 1985 telah berhasil merumuskan 8 asas hukum perikatan nasional, antara lain sebagai berikut:

1) Asas Kepercayaan.

Asas Kepercayaan mengandung pengertian bahwa setiap orang yang akan mengadakan perjanjian akan memenuhi setiap prestasi yang diadakan diantara mereka dibelakang hari.

2) Asas Persamaan Hukum.

Bahwa subjek hukum yang mengadakan perjanjian mempunyai kedudukan, hak dan kewajiban yang sama dalam hukum. Mereka tidak membedakan antara satu sama lain, walaupun subjek hukum itu berbeda ras, agama maupun warna kulit.

3) Asas Keseimbangan.

Adalah asas yang mengkehendaki kedua belah pihak memenuhi dan melaksanakan perjanjian. Kreditur mempunyai kekuatan hukum untuk menuntut pelunasan prestasi melalui kekayaan debitur, namun debitur memikil pula kewajiban untuk melaksanakan perjanjian itu dengan itikad baik.

4) Asas Kepastian Hukum.

Perjanjian sebagai figure hukum harus mengandng kepastian hukum. Kepastian ini terugkap dari kekuatan mengikat perjanjiannya, yaitu sebagai und ang-undang yang membuatnya.

5) Asas Moral.

Asas moral ini terikat dalam perikatan wajar, yaitu suatu perbuatan sukarela dari seseorang tidak menuntut hak baginya untuk menggugat dari pihak debitur.

6) Asas Kepatutan.

${ }^{13}$ Santiago Faisal, Pengantar Hukum Bisnis, Mitra Wacana Media, Jakarta, 2012, h.19.

${ }^{14}$ Ibid, h.20. 


\section{(ㄷ)}

\section{Jurnal Ilmiah METADATA}

Asas kepatutan tertuang dalam Pasal 1339 KUHPerdata yang berbubta"persetujuan-persetujuan tidak hanya mengikat untuk hal-hal yang dengan tegas dinyatakan didalamnya, tetapi juga untuk segala sesuatu yang menurut sifat persetujuan, diharuskan oleh kepatutan, kebiasaan atau undang-undang". Asas ini berkaitan dengan ketentuan mengenai bukti perjanjian.

7) Asas Kebiasaan.

Asas ini dipandang sebagai bagian dari perjanjian. Suatu perjanjian yang tidak hanya mengikat untuk apa yang secara tegas diatur, akan tetapu juga hal-hal yang menurut kebiasaan lazim diikuti.

8) Asas Perlindungan.

Asas perlindungan mengandung pengertian bahwa antara debitur dan kreditur harus dilindungi oleh hukum. Namun, yang perlu dapat perlindungan itu adalah pihak debitur karena pihak debitur berada dipihak yang lemah. ${ }^{15}$

Asas-asas inilah yang menjadi dasar pijakan dari para pihak dalam menentukan dan membuat kontrak guna menjalankan bisnis tersebut. Sehungga pada suatau kondisi tertentu jika terjadi konflik dapat diselesaikan berdasarkan dengan perjanjian yang dibuatnya, bukan berdasarkan atas kebiasaan dan kelaziman tetapi hukumlah yang membuat perjanjian diantara kedua belah pihak. Karena hal ini menjadi suatu kekuatan hukum.

\section{Transaksi Jual-beli On-line.}

1. Pengertian Transaksi Jual-beli

"Transaksi adalah suatu aktivitas perusahaan yang menimbulkan perubahan terhadap posisi harta keuangan perusahaan, misalnya seperti menjual, membeli, membayar gaji, serta membayar berbagai macam biaya lainnya". ${ }^{16}$

Jenis-jenis transaksi:

a) Transaksi internal adalah suatu transaksi yang terjadi yang melibatkan hanya bagian-bagian yang terdapat di dalam perusahaan saja, lebih menekankan perubahan posisi keuangan yang terjadi antara bagian yang ada dalam perusahaan misalnya seperti memo dari pimpinan kepada seseorang yang ditunjuk, perubahan nilai dari harta kekayaan karena penyusutan, dan perlengkapan kantor.

b) Transaksi eksternal adalah suatu transaksi yang melibatakan pihak dari luar perusahaan. Seperti misalnya: transaksi penjualan, pembelian, pembayaran hutang piutang dan lain-lain.

Pengertian jual-beli adalah transaksi antara satu orang dengan orang yang lain yang berupa tukar-menukar suatu barang dengan barang yang lain berdasarkan tata cara atau akad tertentu. "Jual-beli juga merupakan perjanjian timbal balik

15 Wawan Muhwan Hariri, Hukum Perikatan Dilengkapi Hukum Perikatan Dalam Islam, Cv. Pustaka Setia, Bandung, 2011,145.

16 http://www.pengertianku.net/2014/12/pengertian-transaksi-dan-bukti-transaksiterlengkap.html diakses selasa 7 May 2020, diakses Pukul 22.54 WIB. 


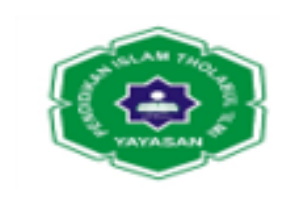

\section{Jurnal Ilmiah METADATA}

dimana pihak penjual berjanji untuk menyerahkan hak milik atas suatu benda sedangkan pembeli berjanji untuk membayar harganya yang terdiri atas sejumlah uang sebagai imbalan dari perolehan hak milik tersebut". ${ }^{17}$ "Perjanian yang terjadi diantara para pihak dilakukan secara elektronik juga, dan tidak ada berkas perjanjian seperti pada transaksi jual-beli lainnya". ${ }^{18}$

"Sedangkan definisi perjanjian menurut Subekti adalah suatu peristiwa dimana seseorang berjanji kepada orang lain atau dimana dua orang itu saling berjanji untuk melaksanakan sesuatu hal, kemudian dari peristiwa ini timbul suatu hubungan perikatan". ${ }^{19}$

\section{Pengertian Transaksi Jual-beli On-line}

Jual-beli adalah persetujuan saling mengikat antara penjual, yakni pihak yang menyerahkan barang, dan pembeli sebagai pihak yang membayar harga barang yang dijual. On-line adalah keadaan terkoneksi dengan jaringan internet. Dalam keadaan on-line kita dapat melakukan kegiatan secara aktif di inretnet sehingga dapat menjalin komunikasi, baik komunikasi satu arah seperti membaca berita dan artikel dalam website maupun komunikasi dua arah seperti chatting dan saling berkirim email. Teknologi Internet mempunyai pengaruh yang sangat besar terhadap perekonomian dunia.

Internet membawa perekonomian dunia memasuki babak baru yang lebih populer dengan istilah digital economics atau perekonomian digital. "Makin banyak kegiatan perekonomian dilakukan melalui media internet, misalnya, semakin banyak mengandalkan jual-beli sistem on-line (e-commerece) sebagai media transaksi". ${ }^{20}$

Elektronik commerece atau disingkat dengan E-commerece adalah kegiatan-kegiatan bisnis yang menyangkut konsumen (consumers), menufactur, services providers dan pedagang perantara (intermediateries) dengan menggunakan jaringan-jaringan komputer (computernetwork) yaitu internet. "Penggunaan sarana internet merupakan kemajuan teknologi yang dapat dikatakan menunjang secara keseluruhan spektrum kegiatan komersial". ${ }^{21}$

"E-commerece pada dasarnya merupakan suatu kontak transaksi perdagangan antara penjual dan pembeli dengan menggunakan media internet jadi proses pemesanan barang, pembayaran transaksi hingga pengiriman barang dikomunikasikan melalui internet". 22 "E-commerece juga dapat diartikan sebagai suatau proses berbisnis dengan memakai teknologi elektronik yang menghubungkan antara perusahan, penjual, pembeli dan masyarakat dalam bentuk

17 Djoko Prakoso dan Bambang Riyadi Liany, Dasar Hukum Persetujuan Tertentu di Indonesia, Jakarta, Bina Aksara, 1987, h.1.

18 Asril Sitompul, Hukum Internet, Bandung, Citra Aditya bakti, 2004, h.55.

${ }^{19}$ Subekti, Pokok-pokok Hukum Perdata, Jakarta, Intermasa, 2003, h.5.

${ }^{20}$ Riyeke Ustadiyanto, Framework E-Commerece, Yogyakarta, ANDI, 2002, h.11.

21 Abdul halim Barakatullah dan Teguh Prasetyo, Bisnis E-Commerece Study System kemananan dan Hukum di Indonesia, Jakarta, Pustaka Pelajar, 2006, h.10.

${ }^{22}$ Ibid, h. 11. 


\section{(ㄷ)}

\section{Jurnal Ilmiah METADATA}

transaksi elektronik dan pertukaran atau penjualan barang, service, dan informasi secara elektronik". ${ }^{23}$

"Dari pengertian-pengertian tersebut maka kita dapat menyimpulkan bahwa pengertian dari Transaksi jual-beli on-line adalah transaksi yang dilakukan penjual dan pembeli secara on-line melalui media internet, tidak ada perjumpaan langsung antara pembeli dan penjual". ${ }^{24}$ Transaksi Elektronik menurut Undang-Undang Republik Indonesia Nomor 11 Tahun 2008 ad alah perbuatan hukum yang dilakukan dengan menggunakan komputer, jaringan komputer, dan/atau media elektronik lainnya.

\section{Jenis-jenis Jual-beli On-line}

Beberapa jenis-jenis dalam jual-beli on-line antara lain sebagai berikut:

a) Transfer Antar Bank

Jual-beli antar bank adalah jenis transaksi yang paling umum dan paling banyak dilakukan di Indonesia. Cara ini yang paling sederhana dan paling gampang di chek oleh penerima atau penjual. Biasanya prosesnya adalah si pembeli melakukan transfer uang pada penjual lalu si penjual akan mengirimkan produk yang dibeli orang tersebut. Kelemahan sistem ini adalah tidak adanya verifikasi mengenai identitas penjual dan hanya mensyaratkan kepercayaan yang tinggi antara dua belah pihak. Padahal bisa jadi nama yang digunakan dalam sosial media-pun bukan nama asli atau bukan identitas yang jelas. Maka seringkali ada kasus penipuan dengan model transaksi seperti ini. Agar tak termakan jebakan penipuan, sebaiknya calon pembeli mencari informasi mengenai profil si penjual. Lebih baik lagi jika dapat mengetahui pengalaman si penjual pada transaksi-transaksi sebelumnya dari berbagai informasi di internet.

b) Cash on Delivery (COD)

Transaksi COD (Cash on Delivery) adalah transaksi yang mempertemukan antara penjual dan pembeli. Sistem kepercayaan dalam model transaksi ini jauh lebih kuat karena penjual dan pembeli bertemu langsung dan bisa melakukan tawarmenawar pembeli juga bisa memeriksa keadaan barang yang akan dibelinya. Biasanya model transkasi seperti ini digunakan oleh para penjual dan pembeli yang melakukan ual beli barang bekas.

c) Rekening Bersama (RekBer)

Rekening bersama atau biasa di sebut RekBer adalah model transaksi yang dianggap paling aman dan sedang sangat populer dalam jagat belanja on-line saat ini. Rekening bersama atau sering disebut escrow adalah rekening yang disediakan toko on-line bekerjasama dengan lembaga keuangan yang telah dipercaya untuk mengelola rekening bersama ini.

Proses transaksi ini mengharuskan pembeli mengirimkan uang kepada sebuah rekening bersama yang telah disediakan toko on-line atau perusahan $e$ commerce bersangkutan dan memiliki reputasi yang sangat terpercaya. Setelah

23 Munir Fuady, Hukum Kontrak Dari Sudut Pandang Hukum Bisnis, Bandung, Citra Aditya Bakti, 2001, h.10.

24 Sora, Pengertian Online dan Offline Secara Lebih Jelas, http://www.pengertianku.net/2015/01/pengertian-online-dan-offline-secara-lebih-jelas.html diakses selasa 7 May 2020 pukul21.23 WIB. 


\section{(ㄷ)}

\section{Jurnal Ilmiah METADATA}

uang masuk, pihak rekening bersama akan memberitahu pada pemilik barang untuk mengirimkan barang atau produk toko on-line-nya. "Setelah barang diterima konsumen dan sudah sesuai pesanan, pihak rekening bersama akan mengirimkan uang kepada pihak penjual". ${ }^{25}$

\section{Pihak-pihak dalam Transaksi Electronic Commerce (E-commerce)}

Transaksi e-commerce melibatkan beberapa pihak, baik yang terlibat secara langsung maupun secara tidak langsung, tergantung kompleksitastransaksi yang dilakukan. Artinya apakah semua proses transaksi dilakukan secara on-line atau hanya beberapa tahap saja yang dilakukan secara on-line. Apabila seluruh transaksi e-commerce dilakukan secara on-line, mulai dari proses terjadinya transaksi sampai dengan pembayaran, maka pihak-pihak yang terlibat terdiri dari :

a) Penjual (merchant), yaitu perusahaan/produsen yang menawarkan produknya melalui internet. Untuk menjadi merchant, maka seseorang hams mendaftarkan diri sebagai merchant account pada sebuah bank, tentunya ini dimaksudkan agar merchant dapat menerima pembayaran dari customer dalam bentuk credit card.

b) Konsumen (Card Holder), yaitu orang-orang yang ingin memperoleh produk (barang atau jasa) melalui pembelian secara on-line. Konsumen yang akan berbelanja di internet dapat berstatus perorangan atau pemIsahaan Apabila konsumen mempakan perorangan, maka perlu di perhatikan dalam transaksi $e$ commerce ad alah bagaimana sistem pembayaran sistem pembayaran dilakukan secara manual/cash. Hal ini penting untuk diketahui mengingat tidak semua konsumen yang berbelanja diinternet adalah pemegang kartu kredit. Pemegang kartu kredit mempakan seseorang yang namanya tercetak pada kartu kredit yang dikeluarkan oleh penerbit berdasarkan perjanjian yang telah dibuat.

c) Acquire, yaitu pihak perantara penagihan (antara penjual dan penerbit) dan perantara pembayaran (antara pemegang dan penerbit). Perantara penagihan adalah pihak yang meneruskan tagihan kepada penerbit berdasarkan tagihan yang masuk kepadanya yang diberikan oleh penjual barang/jasa. Pihak perantara pembayaran (antara pemegang dan penerbit) adalah bank dimana pembayran kredit dilakukan oleh pemilik kartu kredit, selanjutnya bank yang menerima pembayaran ini akan mengirimkan uang pembayaran tersebut kepada penerbit kartu kredit (issuer).

d) Issuer, merupakan perusahaan credit card yang menerbitkan kartu. Di Indonesia ada beberapa lembaga yang diijinkan untuk menerbitkan kartu kredit, yaitu:

1) Bank dan lembaga keuangan bukan bank. Tidak setiap bank dapat menerbitkan credit card, hanya bank yang telah memperoleh ijin dari card International yang dapat menerbitkan credit card, seperti Master dan Visa Card.

2) Perusahaan yang membuka cabang dari perusahaan induk yang ada di luar negeri, yaitu American Express.

25 Onno w. purbo dan Aang Arif Wahyudi,Mengenal e-Commerce, Jakarta, Elex Media Komputindo, 2001, h.192. 


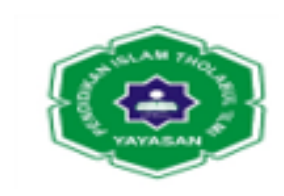

\section{Jurnal Ilmiah METADATA}

e) Certification Authorities, yaitu pihak ketiga yang netral yang memegang hak untuk mengeluarkan sertifikasi kepada merchant, kepada issuer dan dalam beberapa hal diberikan pula kepada card holder. Certification Authorities dapat merupakan suatu lembaga pemerintah atau lembaga swasta.

Apabila transaksi e-commerce tidak sepenuhnya dilakukan secara online dengan kata lain hanya proses transaksinya saja yang melalui media elektronik sementara proses pembayaran tetap dilakukan secara manual/cash, maka pihak acquirer, issuer dan certification authorities tidak terlibat di dalamnya. Disamping pihak-pihak tersebut, pihak lain yang keterlibatannya tidak secara langsung dalam transaksi e-commerce yaitu jasa pengiriman (ekspedisi).

5. Kelebihan dan Kekurangan Jual-beli On-line

a. Kelebihan Jual-beli On-linele-commerce :

1) Aliran pendapatan baru memungkinkan jauh lebih menjanjikan yang tidak ditemui disistem jual-beli pasar tradisional;

2) Mampu meningkatkan market exposure;

3) Mampu mengurangi biaya operasioanal;

4) Dapat memperluas jangkauan;

5) Mampu meningkatkan pelanggan loyalty;

6) Mampu meningkatkan suplier management;

7) Meningkatkan value chain (mata rantai pendapatan). ${ }^{26}$

b. Kekurangan Jual-beli On-linele-commerce :

1) Akan kehilangan dari segi finansial secara langsung karena adanya kecurangan. Seorang menipu mentrasfer uang dari rekening saru kerekening lainnya atau dia telah mengganti data finansial yang ada;

2) Adanya pencurian informasi yang sangat rahasia dan berharga. Gangguan yang muncul bisa membengkar semua informasi rahasia itu pada pihak yang tidak berhak dan mengakibatkan kerugian besar bagi korban;

3) Kehilangan kesempatan bisnis atau kerugian pelanggan karena gangguan pada pelayanan, seperti kesalahan yang bersifat non-teknis;

4) Adanya pengaksesan kesumber pihak yang tidak berhak;

5) Dapat kehilangan sebuah kepercayaan dari para konsumen. Karena faktor-faktor seperti ad anya usaha sengaja yang dilakukan oleh pihak luar yang berusaha menjatuhkan reputasi perusahaan tersebut. Terjadinya kerugian yang tidak terduga-duga, karena adanya gangguan yang dilakukan dengan sengaja, ketidak jujuran, kesalahan dari faktir manusia ataupun kesalahan dari sistem elektronik. ${ }^{27}$

6. Keabsahan Transaksi Jual-beli On-line.

${ }^{26}$ Harman Maulana,Op.Cit., h.306.

${ }^{27}$ Harman Maulana,Op.Cit., h.306. 


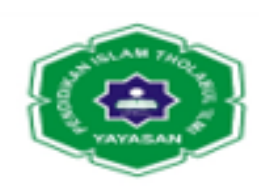

\section{Jurnal Ilmiah METADATA}

Di Indonesia Perjanjian yang berlaku harus didasarkan pada buku ke III KUHPerdata Tentang perikatan. Perikatan terdapat dalam perjanjian karena perikatan dapat ditimbulkan oleh perjanjian disamping oleh Undang-Undang. Hal tersebut diatur dalam Pasal 1233 KUHPerdata yang berbunyi: "Tiap-tiap perikatan dilahirkan baik karena persetujuan baik karena Undang-Undang". "Pengertian perikatan tidak terdapat dalam buku ke III KUHPerdata, akan tetapi menurut ilmu pengetahuan hukum perikatan dapat diartikan sebagai hubungan yang terjadi diantara dua orang atau lebih, yang terletak didalam lapangan harta kekayaan dimana pihak yang satu berhak atas prestasi dan pihak yang lainnya wajib memenuhi prestasi". ${ }^{28}$

Berdasarkan Pasal 1313 KUHPerdata kontrak atau perjanjian adalah suatu perbuatan dengan mana satu orang atau lebih mengikatkan dirinya terhadap satu orang atau lebih. Berbicara masalah keabsahan suatu transaksi, orang selalu akan mendasarkan pada ketentuan dalam Pasal 1320 Kitab Undang-Undang Hukum Perdata yang menyatakan bahwa untuk sahnya suatu perjanjian diperlukan 4 (empat) syarat, yakni:

a) Kesepakatan para pihak;

b) Kecakapan untuk membuat perjanjian;

c) Suatu hal tertentu;

d) Suatu sebab yang halal.

Dengan mendasarkan pada ketentuan Pasal 1320 KUHPerdata sebenarnya tidak dipermasalahkan mengenai media yang digunakan dalam transaksi, atau dengan kata lain Pasal 1320 KUHPerdata tidak mensyaratkan bentuk dan jenis media yang digunakan dalam bertransaksi. Oleh karena itu, dapat saja dilakukan secara langsung maupun secara elektronik. Namun suatu perjanjian dapat dikatakan sah bila telah memenuhi unsur-unsur sebagaimana dimaksud dalam Pasal 1320 tersebut.

Demikian pula asas kebebasan berkontrak yang dianut KUHPerdata, dimana para pihak dapat bebas menentukan danmembuat suatu perikatan atau perjanjian dalam bertransaksi yang dilakukandengan itikad baik (Pasal 1338). Jadi apapun bentuk dan media dari kesepakatan tersebut, tetap berlaku dan mengikat para pihak karena perikatan tersebut merupakan undang-undang bagi yang membuatnya.

Permasalahan akan timbul dari suatu transaksi bila salah satu pihak ingkar janji. Penyelesaian permasalahan yang terjadi tersebut, selalu berkaitan dengan apayang menjadi bukti dalam transaksi, lebih-lebih bila transaksi menggunakan sarana elektronik. Hal ini karena penggunaan dokumen atau data elektronik sebagai akibat transaksi melalui media elektronik, belum secara khusus diatur dalam hukum acara yang berlaku, baik dalam Hukum Acara Perdata maupun dalam Hukum Acara Pidana. Mengenai hukum materiilnya pada dasarnya sudah secara tegas diatur dalam Pasal 15 ayat (1) Undang-Undang Nomor 8 Tahun 1997 tentang Dokumen Perusahaan yang menyatakan bahwa "dokumen perusahaan yang telah dimuat

${ }^{28}$ Mariam Darus Badrulzaman, Hukum Perdata buku III Dengan Penjelasan, Bandung, Alumni, 1983. 


\section{(ㄷ)}

\section{Jurnal Ilmiah METADATA}

dalam microfilm atau mendia lainnya dan atau hasil cetaknya merupakan alat bukti yang sah".

Selanjutnya apabila kita perhatikan ketentuan dalam Pasal 1 angka 2 mengenai pengertian dokumen dan dikaitkan dengan ketentuan Pasal 12 ayat (1) dan ayat (2) Undang-Undang Nomor 8 Tahun 1997 jo. Pasal 1320 KUHPerdata, transaksi melalui media elektronik adalah sah menurut hukum.

\section{Tinjauan Hukum Transaksi On-line Dalam UU ITE}

a. Transaksi elektronik adalah perbuatan hukum yang dilakukan dengan menggunakan komputer, jaringan komputer dan/atau media elektronik lainnya (diatur dalam Pasal 1 ayat 2 Undang-Undang No. 19 Tahun 2016 Tentang Informasi Dan Transaksi Elektronik).

b. Badan usaha adalah perusahaan perseorangan atau perusahaan persekutuan, baikyang berbadan hukum maupun yang tidak berbadan hukum (diatur dalam Pasal 1 ayat 22 Undang-Undang No. 19 Tahun 2016 Tentang Informasi Dan Transaksi Elektronik).

c. Undang-Undang ini berlaku untuk setiap orang yang melakukan perbuatan hukum yang sebagaimana diatur dalam Undang-Undang ini, baik yang berada di wilayah hukum Indonesia maupun yang berada diluar wilayah hukum indonesia, yang memiliki akibat hukum di wilayah hukum Ind onesia dan/atau diluar wilayah hukum Indonesia (diatur dalam Pasal 2 UndangUndang Nomor 19 tahun 2016 Tentang Informasi Dan Transaksi Elektronik).

d. Pelaku usaha yang menawarkan produk melalui sistem elektronik harus menyediakan informasi yang lengkap dan bener berkaitan dengan syarat kontak, produsen dan produk yang di tawarkan (diatur dalam Pasal 9 Undang-Undang No. 19 Tahun 2016 Tentang Informasi Dan Transaksi Elektronik).

e. Setiap pelaku usaha yang menyelenggarakan transaksi elektronik dapat di sertifikasi oleh lembaga sertifikasi keandalan (diatur dalam Pasal 10 Undang-Undang No. 19 Tahun 2016 Tentang Informasi Dan Transaksi Elektronik).

f. Transaksi elektronik selanjutnya diatur lebih lanjut pada Bab V Pasal 17, 18, 19 20, 21, 22, Undang-Undang No. 19 Tahun 2016 Tentang Informasi Dan Transaksi Elektronik).

g. Setiap orang dapat mengajukan gugatan terhadap pihak yang menyelenggarakan sistem elektronik dan/atau menggunakan teknologi informasi yang menimbulkan kerugian (Pasal 38 Undang-Undang No. 19 Tahun 2016 Tentang Informasi Dan Transaksi Elektronik).

\section{B. Penerapan Hukum Terhadap Asas Kepercayaan Jual-beli On-line}

Jual-beli adalah suatu kontrak dimana satu pihak yang disebut dengan penjual, mengikatkan dirinya untuk menyerahkan suatu benda, sedangkan pihak lainnya, yang disebut sebagai pihak pembeli mengikatkan dirinya untuk 


\section{(ㄷ)}

\section{Jurnal Ilmiah METADATA}

membayar harga barang atau jasa tersebut sebesar yang telah disepakati bersama. $^{29}$

Inti dari jual-beli adalah kata sepakat, karena dalam Pasal 1313 KUHPerdata disebutkan bahwa suatu perjanjian adalah suatu perbuatan dimana satu orang atau lebih mengikatkan diri terhadap satu orang atau lebih. Bila pembeli melakukan persetujuan/kata sepakat dengan penjual maka terjadilah jual-beli tersebut.

"E-Commerce dapat diartikan sebagai suatu proses berbisnis dengan memakai teknologi elektronik yang menghubungkan antara perusahaan, konsumen, dan masyarakat dalam bentuk transaksi elektronik dan pertukaran /penjualan barang, servis, dan informasi elektronik". ${ }^{30}$ Transaksi melalui internet atau yang disebut e-commerce pada dasarnya sudah dikenal di Indonesia pada waktu yang cukup lama. Hubungan-hubungan hukum yang terjadi antara pihak yang menggunakan fasilitas internet berdasarkan subjek hukum dapat dikelompokkan dalam:

1) Business to business;

2) Business to customer;

3) Cutomer to customer;

4) Customer to business;

5) Customer to government.

"Perjanjian jual-beli pada umumnya merupakan perjanjian konsensual karna mengikat para pihak saat terjadinya kesepakatan para pihak tersebut mengenai unsur esensial dan aksidentalia dari perjanjian tersebut". ${ }^{31}$ Dikatakan adanya kesepakatan mengenai unsur esensial dan aksidentalia karena walaupun para pihak sepakat mengenai barang dan harga, jika ada hal-hal lain yang tidak disepakati yang terkait dengan perjanjian jual-beli tersebut jual-beli tetap tidak akan terjadi karena tidak ada kata kesepakatan.

Kesepakatan dalam perjanjian jual-beli yang pada umumnya melahirkan perjanjian jual-beli, dikecualikan apabila barang yang diperjual-belikan tersebut adalah barang yang harus dicoba dulu untuk mengetahui apakah barang tersebut baik atau sesuai dengan keinginan pembeli. Dalam Pasal 1338 KUHPerdata menyebutkan bahwa "suatu perjanjian harus dilaksanakan dengan itikad baik".

Asas ini merupakan asas bahwa para pihak, yaitu pihak kreditur dan debitur melaksanakan substansi kontrak berdasarkan kepercayaan atau keyakinan yang teguh maupun kemauan baik dari para pihak. Dalam hukum perjanjian dikenal asas itikad baik, yang artinya bahwa setiap orang yang membuat perjanjian harus dilakukan dengan dasar kepercayaan. Asas kepercayaan ini dapat dibedakan atas kepercayaan yang subjektif dan kepercayaan yang objektif. Kepercayaan dalam pengertian subjektif dapat diartikan sebagai kejujuran seseorang atas dalam

${ }^{29}$ Munir Fuady, Pengantar Hukum Bisnis Menata Bisnis Modern di Era Global Cetakan III, PT. Citra Aditya Bakti, Bandung, 2008, h.25.

${ }^{30}$ Munir Fuadi, Dari sudut pandang Hukum Bisnis, Citra Aditya Bakti, Bandung, 2003, h.407.

${ }^{31}$ Ibid, h.126. 


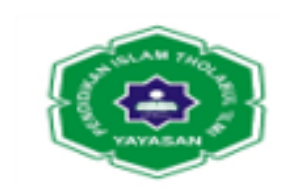

\section{Jurnal Ilmiah METADATA}

melakukan suatu perbuatan hukum yaitu apa yang terletak pada sikap batin seseorang pada saat diadakan suatu perbuatan hukum. Sedang kepercayaan dalam pengertian yang objektif dimaksudkan adalah pelaksanaan suatu perjanjian yang harus didasarkan pada norma kepatutan atau apa yang dirasakan patut dalam suatu masyarakat.

Dapat diketahui bahwa ada sangat banyak sekali faktor untuk membuat pembeli on-line dan penjual on-line untuk mendapatkan kepercayaan antara mereka, seperti unsur subjektif yang dijelaskan diatas bahwa kepercayaan antara mereka, seperti unsur subjektif yang dijelaskan di atas bahwa pembeli maupun penjual akan mendapatkan kepercayaan mereka salah satunya melalui chat antara penjual dan pembeli, pada saat melakukan chat apakah pembeli merasa nyaman dengan penjual toko tersebut atau tidak. Setelah mendapatkan unsur subjektif tersebut adapula unsur objektif yang mana setelah para penjual dan pembeli melakukan perjanjian jual-beli On-line dan telah sepakat melakukan transaksi maka transaksi tersebut akan mengikat kepada para pihak seperti telah diatur dalam Pasal 1338 KUHPerdata.

Dalam Pasal 17 ayat 2 Undang-Undang Informasi dan Transaksi Elektronik telah ditegaskan bahwa para pihak yang melakukan transaksi elektronik wajib beritikad baik dalam melakukan interaksi atau pertukaran informasi elektronik dan atau dokumen elektronik selama transaksi berlangsung. Sedangkan asas kepercayaan di dalam jual-beli on-line para pihaknya timbul dengan sendirinya dengan menguntungkan satu sama lain dan tidak merugikan satu sama lain. Asas kepercayaan ini sangat lah penting bagi kedua belah pihak dalam melakukan transaksi jual-beli on-line melalui media elektronik karena sangat menunjang didalam proses tersebut agar tercipta prestasi yang diingikan oleh kedua belah pihak.

Asas kepercayaan diantaranya adalah seseorang yang mengadakan perjanjian dengan pihak lain yang menumbuhkan kepercayaan diantarakedua belah pihak, dimana satu sama lain akan memegang janjinya dalam jual-beli on-line. Dalam arti kata mereka yang melakukan jual-beli on-line tersebut akan memenuhi prestasinya, tanpa adanya kepercayaan maka para pihak akan merasa tidak nyaman dalam melakukan perjanjian jual-beli on-line.

Hal utama yang perlu dipertimbangkan dalam jual-beli on-line adalah seorang pembeli ketika melakukan kegiatan belanja on-line adalah apakah mereka percaya terhadap website yang menyediakan fasilitas layanan on-line shop dan percaya kepada penjual on-line yang ad a dalam d situs web tersebut. Hal utama yang perlu dipertimbangkan seorang pembeli adalah ketika melakukan kegiatan belanja secara on-line adalah apakah mereka percaya terhadap website yang menyediakan fasilitas layanan on-line dan percaya pada penjual on-line, karena kepercayaan adalah faktor penting dalam membangun komitmen antara penjual dan pembeli. 


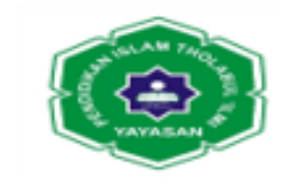

Jurnal Ilmiah METADATA

\section{KESIMPULAN}

3. Keabsahan jual-beli secara on-line dapat menerapkan KUHPerdata sebagai dasar diakuinya keabsahannya dimana syarat sahnya perjanjian tercantum dalam Pasal 1320 KUHPerdata, dan mengacu pada Pasal 19 dan 20 UndangUndang Nomor 19 Tahun 2016 Tentang Informasi dan Transaksi Elektronik bahwa para pihak yang melakukan transaksi elektronik harus menggunakan sistem elektronik yang disepakati.

4. Penerapan hukum terhadap asas kepercayaan dalam transaksi jual-beli terdapat dalam Pasal 1338 KUHPerdata yaitu bahwa dalam melakukan suatu perjanjian harus di laksanakan dengan itikad baik. Sehingga dapat menimbulkan kepercayaan terhadap pelanggan. Kepercayaan sangat berperan penting dalam perdagangan melalui media elektronik. Faktor kepercayaan menjadi faktor kunci. Tanpa ada kepercayaan dari pelanggan, mustahil transaksi e-commerce akan terjadi. Maka dari itu pentingnya dalam menawarkan produk usaha melalui media maya atau internet memberikan informasi yang baik dan benar sehingga memberikan kepastian hukum kepadakonsumen dikemudian hari apabila terjadi sengketa atas barang yang tidak kunjung datang, cacat, maupun hilang.

\section{DAFTAR PUSTAKA}

\section{A. Buku}

Abdul halim Barakatullah dan Teguh Prasetyo, Bisnis E-Commerece Study System Kemananan dan Hukum di Indonesia, Jakarta, Pustaka Pelajar, 2006.

Abdul Kadir Muhammmad, Hukum Perjanjian, Bandung, PT. Citra Aditya Bakti, 2006.

Asril Sitompul, Hukum Internet, Bandung, Citra Aditya bakti, 2004.

Assafa Endeshaw, Hukum E-Commerece dan Internet dengan Fokus di Asia Pasifik, Yogyakarta, Pustaka Pelajar, 2007.

Djoko Prakoso dan Bambang Riyadi Liany, Dasar Hukum Persetujuan Tertentu di Indonesia, Jakarta, Bina Aksara, 1987. 
Jurnal Ilmiah METADATA

E.S. Wiradipradja dan D. Budhijanto, Perspektif Hukum Internasional tentang Cyber Law dalam Kantaatmadja, et al, Cyberlaw : Suatu Pengantar, Jakarta, Elips 11, 2002.

Hardijan Rusli, Hukum Perjanjian Indonesia dan Common Law, Jakarta, Pustaka Sinar Harapan, 1993.

Harman Malau, Manajemen Pemasaran Teori Dan Aplikasi Pemasaran Era Traditisional Sampai Era Modernisasi Global, Cv. Alfabeta, Bandung, 2018.

Hermansyah, Perwujudan Asas Kepercayaan Dalam Pengaturan Kegiatan Usaha Bank, Skripsi Sarjana, Fakultas Ilmu Hukum Universitas, Tanjungpura, Pontianak, 2015.

Hikmahanto Juwana, Hukum Ekonomi dan Hukum Internasional, Jakarta, Lentera Hati, 2002.

Kartini Muljadi dan Gunawan Widjaja, Seri Hukum Perikatan, Jakarta, Raja Grafindo Persada, 2003.

Mariam Darus Badrulzaman, Hukum Perdata Buku III Dengan Penjelasan, Bandung, Alumni, 1983.

M Nasrullah Yusuf, Strategi Membangun Nilai Jasa dan Kepercayaan Pelanggan, Jakarta, Deepublish, 2014.

------, E-Commerce Tinjauan Dari Hukum Kontrak Indonesia, Jakarta, Citra Aditya Bakti, 2001.

Munir Fuady, Dari sudut pandang Hukum Bisnis, Bandung, Citra Aditya Bakti, 2003.

------, Pengantar Hukum Bisnis Menata Bisnis Modern di Era Global Cetakan III, Bandung, PT. Citra Aditya Bakti, 2008.

------, Hukum Kontrak Dari Sudut Pandang Hukum Bisnis, Bandung, Citra Aditya Bakti, 2001.

Onno W. Purbo dan Aang Arif Wahyudi, Mengenal E-Commerce, Jakarta, Elex Media Komputindo, 2001. 
Riyeke Ustadiyanto, Framework E-Commerece, Yogyakarta, ANDI, 2002.

R. Subekti, Hukum Perjanjian, PT. Intermasa, Jakarta, 2002.

Salim HS, Hukum Kontrak: Teori dan Teknik Penyusunan Kontrak, Jakarta, Sinar Grafika, 2006.

Santiago Faisal, Pengantar Hukum Bisnis, Mitra Wacana Media, Jakarta, 2012.

Subekti, Pokok-Pokok Hukum Perdata, Jakarta, Intermasa, 2003.

Wawan Muhwan Hariri, Hukum Perikatan Dilengkapi Hukum Perikatan Dalam Islam, Cv. Pustaka Setia, Bandung, 2011.

\section{B. Perundang-Undang}

Kitab Undang-Undang Hukum Perdata.

Undang-Undang Nomor 8 Tahun 1997 tentang Dokumen Perusahaan.

Undang-Undang Nomor 19 Tahun 2016 Tentang Informasi Dan Transaksi Elektronik.

\section{Internet}

http://www.pengertianku.net/2015/01/pengertian-on-line-dan-offline-secara-lebihjelas.html diakses selasa 7 May 2020 pukul 21.23 WIB

http://www.pengertianku.net/2014/12/pengertian-transaksi-dan-bukti-transaksiterlengkap.html diakses selasa 7 May 2020 pukul 22.54 WIB 